\title{
Capacity of simultaneous removal of zinc and cadmium from contaminated media, by two microalgae isolated from a polluted site
}

\author{
Cristina M. Monteiro - Paula M. L. Castro • \\ F. Xavier Malcata
}

\begin{abstract}
Several aquatic environments have been contaminated with heavy metals dumped via industrial effluents. Numerous studies have been published regarding the removal of single metals from aqueous solutions by microalgal biomass. However, such studies do not reflect the actual problem associated with industrial effluents because usually more than one metal species is present. Here we studied the biosorption capacity of $\mathrm{Zn}^{2+}$ and $\mathrm{Cd}^{2+}$ as single- and binarymetal systems by two microalgae, Scenedesmus obliquus and Desmodesmus pleiomorphus, isolated from a polluted site in Northern Portugal. For each metal independently, D. pleiomorphus showed a higher metal sorption capacity than $S$. obliquus, at concentrations ranging from 60 to $300 \mathrm{mg} / \mathrm{l}$ (except $150 \mathrm{mg}_{\mathrm{Cd}} / \mathrm{l}$ ). Maximum amounts of $\mathrm{Zn}^{2+}$ and $\mathrm{Cd}^{2+}$ removed were 22.3 and $60.8 \mathrm{mg} / \mathrm{g}$ by $S$. obliquus, and 83.1 and $58.6 \mathrm{mg} / \mathrm{g}$ by $D$. pleiomorphus. In binary-metal solutions, S. obliquus was in general able to remove $\mathrm{Zn}^{2+}$ to higher extents than $\mathrm{Cd}^{2+}$, whereas the opposite was observed with $D$. pleiomorphus. The simultaneous uptake of $\mathrm{Zn}^{2+}$ and $\mathrm{Cd}^{2+}$ by both microalgae was considerably lower than that of
\end{abstract}

C. M. Monteiro - P. M. L. Castro

CBQF/Escola Superior de Biotecnologia, Universidade Católica Portuguesa, Rua Dr. António Bernardino de Almeida,

4200-072 Porto, Portugal

F. X. Malcata $(\bowtie)$

ISMAI, Instituto Superior da Maia, Avenida Carlos Oliveira Campos, Castelo da Maia, 4475-690 Avioso S. Pedro, Portugal

e-mail: fmalcata@ismai.pt

F. X. Malcata

CIMAR/CIIMAR, Centro Interdisciplinar de Investigação Marinha e Ambiental, Rua dos Bragas no. 289, 4050-123 Porto, Portugal their single-metal counterparts, at equivalent concentrations. Although microalgal uptake from binary-metal solutions was lower than from single-metal ones, the wild microalgae selected were able to efficiently take up mixtures of $\mathrm{Zn}^{2+}$ and $\mathrm{Cd}^{2+}$ up to $300 \mathrm{mg} / \mathrm{l}$ of both metals-thus materializing a promising bioremediation vector for polluted waters.

Keywords Scenedesmus obliquus - Desmodesmus pleiomorphus - Simultaneous biosorption - Binary mixture . Heavy metals $\cdot \mathrm{Zn}$ and $\mathrm{Cd}$

\section{Introduction}

Pollution of aquatic environments by toxic heavy metals has been taking place because of discharge of untreated effluents from many industrial processes. The environmental injuries brought about by such effluents have received major attention by national and international authorities, and consequently led to directives and regulations aimed at minimizing their impact. In attempts to remove (or, at least, reduce the concentration of) those toxic metals, distinct types of microbial biomass have been scrutinized as alternatives to conventional physicochemical technologies (Aksu and Dönmez 2006; Puranik and Paknikar 1999; Sağ et al. 2000; Vilar et al. 2008); the latter are in fact characterized by a limited effectiveness, and are typically too expensive when the target metal concentration is at the ppm level or below (Fraile et al. 2005).

One type of biomass useful for bioremediation is that from microalgae. The capacity of these microorganisms to remove heavy metals has mainly been attributed to metal adsorption onto their cell wall, by both electrostatic attraction and complexation (Aksu and Dönmez 2006; Mehta and Gaur 2005). The cell wall of microalgal cells 
includes indeed several macromolecules that act as polyelectrolytes owing to their charged side groups, and thus provide binding sites for the aforementioned metal ions (Mehta and Gaur 2005; Puranik and Paknikar 1999); the presence of anionic and cationic sites brings about amphoteric properties for the cell wall.

Most experimental data available in the literature pertain, however, to single-metal biosorption by microalgae; multi-metal systems have received a poor attention by researchers, maybe because of their intrinsically higher complexity arising from the possible interactions among solutes. However, wastewaters normally contain more than one type of metal ion, so each metal may interfere with removal and/or recovery of other metal(s) of interest (Aksu and Dönmez 2006; Puranik and Paknikar 1999). It is known that the extent of metal removal depends on intrinsic factors, such as specific surface properties of the microorganism, and extrinsic factors, such as temperature, $\mathrm{pH}$, metal ion concentration and biomass concentration (Aksu and Dönmez 2006; Mehta and Gaur 2005). Furthermore, the presence of other cations may hamper sorption of a given metal by biomass: the capacity of microorganisms to bind more than one metal species depends, in fact, on several extra parameters, e.g. metal ion combination, metal ion concentrations and order of metal addition (Ting et al. 1991).

Competition among the various metal ions in solution for microalga surface binding sites will likely occur, depending on their specific features as cations (Aksu and Dönmez 2006; Aksu et al. 1999). A mixture of metal ions can typically produce three types of behaviour: synergism, antagonism or no interaction at all; however, which specific behaviour will take place cannot be anticipated solely on the basis of single-metal studies (Aksu et al. 1999; Puranik and Paknikar 1999). Consequently, a practical need exists for studying the removal process in multiple-metal solutions, at least binary ones.

The objective of the present study was thus to assess the performance of two wild microalgae in removal of $\mathrm{Zn}^{2+}$ and $\mathrm{Cd}^{2+}$ from aqueous solutions of single- and binarymetal systems - and to determine the combined effects of these metal ions on the bioaccumulation capacity of $S$. obliquus and D. pleiomorphus.

\section{Experimental procedure}

Microalga sources and culture conditions

The test microalgae, Scenedesmus obliquus and Desmodesmus pleiomorphus, were isolated from a heavymetal-contaminated region of Northern Portugal, "Esteiro de Estarreja" (Monteiro et al. unpublished), where $\mathrm{Zn}$ appears as a major contaminant (Oliveira et al. 2001); hence, their intrinsic capacity for metal uptake was expected to be high enough for eventual bioremediation on larger scale. Both microalga species were cultured in OHM medium (Bishop and Senger 1971) in the absence of EDTA, and were maintained at $25^{\circ} \mathrm{C}$ under continuous lighting. Inocula for all experimental batches were obtained from exponentially growing cultures, based on cell numbers (this status was reached after 2-3 days of growth). All materials and culture media were previously autoclaved at $121^{\circ} \mathrm{C}$ and $1 \mathrm{~atm}$, for $15 \mathrm{~min}$.

\section{Biosorption experiments}

Stock solutions of $\mathrm{Zn}^{2+}(5.0 \mathrm{~g} / \mathrm{l})$ and $\mathrm{Cd}^{2+}(6.0 \mathrm{~g} / \mathrm{l})$ were prepared with the corresponding chloride salts, $\mathrm{ZnCl}_{2}$ and $\mathrm{CdCl}_{2}$, dissolved in deionized water. All glassware material employed was previously rinsed with nitric acid and several times afterwards with deionized water prior to use, so as to guarantee absence of any interferent with the chemical analyses afterwards.

The capacity of each of the two microalga species to remove $\mathrm{Zn}^{2+}$ and $\mathrm{Cd}^{2+}$, both as individual entities and as a mixture, was examined in batch cultures stirred at $100 \mathrm{rpm}$ and kept at $25^{\circ} \mathrm{C}$. The biosorption experiments were performed in triplicate, in glass flasks containing $25 \mathrm{ml}$ of the metal aqueous solutions with the intended concentrations of a single or of the two cations. A defined volume of microalgal culture was then added to the experimental media, in order to achieve an initial cell density of ca. $1 \mathrm{~g} / \mathrm{l}$ dry weight (more specifically, $0.8 \mathrm{~g} / \mathrm{l}$ for $S$. obliquus and $1.0 \mathrm{~g} / \mathrm{l}$ for D. pleiomorphus).

After exposure of the microalgal cells to metal solutions for a period of $2 \mathrm{~h}, 15-\mathrm{ml}$ (duplicated) samples were taken from each flask. They were subsequently centrifuged, and the supernatant was collected for determination of the remaining concentrations of both $\mathrm{Zn}^{2+}$ and $\mathrm{Cd}^{2+}$ in the culture medium by atomic absorption spectrophotometry with flame atomization, using an Unicam 960 (USA) spectrophotometer, at the wavelengths of 213.9 and $228.8 \mathrm{~nm}$ for $\mathrm{Zn}$ and $\mathrm{Cd}$, respectively. Based on previous experience entailing $\mathrm{Zn}^{2+}$ and $\mathrm{Cd}^{2+}$ removal by either microalgal species (Monteiro et al. 2009; 2010a), a 2-h exposure period was chosen for these sorption studies; it had indeed been observed that removal of metal cations by those microalgae is mainly (but not exclusively) by adsorption onto their surface-which is a rapid process that reaches equilibrium after a few minutes of contact. The initial concentrations used were 60,150 and $300 \mathrm{mg} / \mathrm{l}$ in single-metal tests, and $60 \mathrm{mg}_{\mathrm{Zn}} / 1+60 \mathrm{mg}_{\mathrm{Cd}} / 1,60 \mathrm{mg}_{\mathrm{Zn}} /$ $1+300 \mathrm{mg}_{\mathrm{Cd}} / 1, \quad 150 \mathrm{mg}_{\mathrm{Zn}} / 1+150 \mathrm{mg}_{\mathrm{Cd}} / 1, \quad 300 \mathrm{mg}_{\mathrm{Zn}} /$ $1+60 \mathrm{mg}_{\mathrm{Cd}} / 1$ and $300 \mathrm{mg}_{\mathrm{Zn}} / 1+300 \mathrm{mg}_{\mathrm{Cd}} / 1$ in combinedmetal tests. The combinations of $\mathrm{Zn}^{2+}$ and $\mathrm{Cd}^{2+}$ in binary 
solutions were based on a factorial scheme coupled with a sequential dilution strategy. Negative controls (i.e. culture media with the desired metal concentrations, but without microalgal biomass) were considered as well.

\section{Results and discussion}

The capacity of $\mathrm{Zn}^{2+}$ and $\mathrm{Cd}^{2+}$ removal by S. obliquus and D. pleiomorphus, two microalga species isolated from a contaminated location in Northern Portugal, were tested in both single and binary-metal systems. Experimental data on metal removed using the two microalgae, expressed per unit weight of biomass, as well as individual and total removal efficiencies, are presented in Fig. 1, and in Tables 1 and 2. Although more concentration levels could have been in principle tested, the number of experiments to be run under a factorial design would have become unpractical, especially because of the combinations of both metals, so only a 3-point design was pursued.

It has been claimed that the removal capacity of living biomass occurs both by adsorption onto the cell surface and by incorporation inside the cell. However, previous studies have shown that, in the case of the microalgae selected for our study, both $\mathrm{Zn}^{2+}$ and $\mathrm{Cd}^{2+}$ independently were removed chiefly by adsorption onto the cell surface (Monteiro et al. 2010a, b). Although non-living microalgae would thus logically appear as more appropriate, note that passive removal is anyway lower than total removal, and that decay of the adsorbent would be relatively fast if inactivated biomass were employed. On the other hand, the capacity of living biomass to remove heavy metals from solution is likely affected by the toxicity of said heavy metal pollutants, as they cause changes in cell metabolism and growth (Omar 2002); previous studies encompassing $\mathrm{Zn}^{2+}$ and $\mathrm{Cd}^{2+}$ toxicity upon either $S$. obliquus or $D$. pleiomorphus cells (Monteiro et al. 2010c) have indeed demonstrated that growth is significantly affected by the presence of any of those metals, but only at relatively high concentrations-i.e. above the upper bound considered here for the initial heavy metal concentrations. Therefore, resorting to living biomass was a reasonable option.

In Fig. 1, one observes that the amount of $\mathrm{Zn}^{2+}$ accumulated by $D$. pleiomorphus increased with increasing initial metal ion concentration in single-metal ion experiments; regarding exposure to plain $\mathrm{Cd}^{2+}$, an increase in
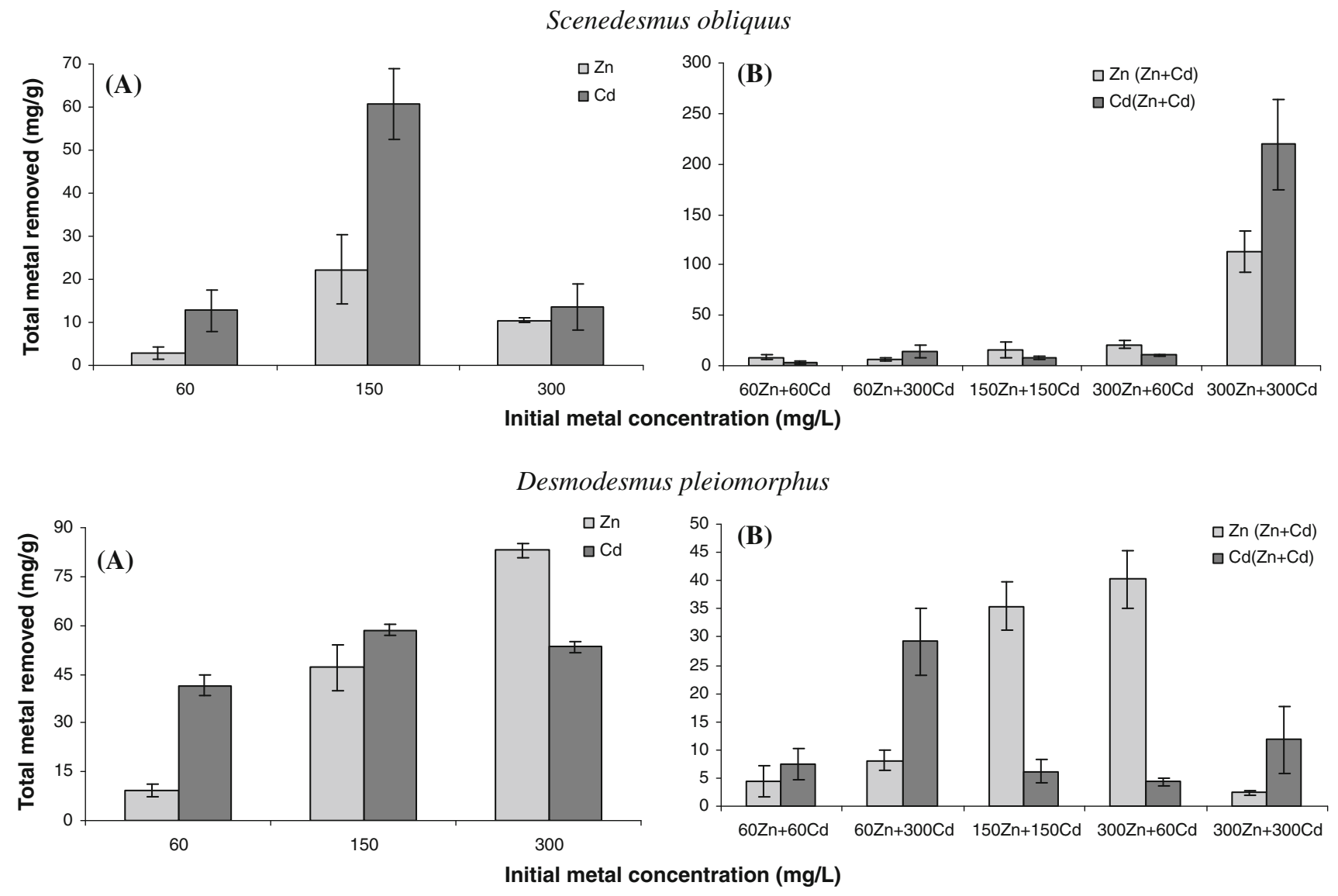

Fig. 1 Extents of $\mathrm{Zn}$ and $\mathrm{Cd}$ removed (average \pm standard deviation) from single (a) and binary (b) metal aqueous solutions, by $S$. obliquus and D. pleiomorphus 
Table 1 Extents of $\mathrm{Zn}^{2+}$ and $\mathrm{Cd}^{2+}$ removed (average \pm standard deviation) by $S$. obliquus at various initial metal concentrations, from singleand binary-metal aqueous solutions, and corresponding bioaccumulation efficiencies

\begin{tabular}{|c|c|c|c|c|c|c|}
\hline $\begin{array}{l}\text { Initial } \mathrm{Zn} \\
\text { concentration } \\
(\mathrm{mg} / \mathrm{l})\end{array}$ & $\begin{array}{l}\text { Initial Cd } \\
\text { concentration } \\
(\mathrm{mg} / \mathrm{l})\end{array}$ & $\begin{array}{l}\text { Total } \mathrm{Zn} \\
\text { removed } \\
(\mathrm{mg} / \mathrm{l})^{\mathrm{a}}\end{array}$ & $\begin{array}{l}\text { Total Cd } \\
\text { removed } \\
(\mathrm{mg} / \mathrm{l})^{\mathrm{a}}\end{array}$ & $\begin{array}{l}\text { Zn removal } \\
\text { efficiency } \\
-Y_{j}(\%)^{\mathrm{b}}\end{array}$ & $\begin{array}{l}\text { Cd removal } \\
\text { efficiency } \\
-Y_{j}(\%)^{\mathrm{b}}\end{array}$ & $\begin{array}{l}\text { Combined removal } \\
\text { Efficiency }-Y_{\text {total }} \\
(\mathrm{Zn}+\mathrm{Cd})(\%)^{\mathrm{c}}\end{array}$ \\
\hline 60 & 0 & $2.3 \pm 1.1$ & - & 3.9 & - & 3.9 \\
\hline 150 & 0 & $17.8 \pm 6.4$ & - & 11.9 & - & 11.9 \\
\hline 300 & 0 & $8.3 \pm 0.4$ & - & 2.8 & - & 2.8 \\
\hline 0 & 60 & - & $10.2 \pm 3.8$ & - & 16.9 & 16.9 \\
\hline 0 & 150 & - & $48.6 \pm 6.6$ & - & 32.4 & 32.4 \\
\hline 0 & 300 & - & $10.8 \pm 4.3$ & - & 3.6 & 3.6 \\
\hline 60 & 60 & $6.8 \pm 1.7$ & $2.9 \pm 1.1$ & 11.2 & 4.8 & 8.1 \\
\hline 60 & 300 & $4.9 \pm 1.2$ & $11.1 \pm 4.7$ & 8.1 & 3.7 & 4.4 \\
\hline 150 & 150 & $12.3 \pm 6.3$ & $6.0 \pm 1.4$ & 8.2 & 4.0 & 6.1 \\
\hline 300 & 60 & $16.7 \pm 3.0$ & $8.3 \pm 0.9$ & 5.6 & 13.8 & 7.0 \\
\hline 300 & 300 & $90.5 \pm 16.3$ & $175.6 \pm 3.6$ & 30.2 & 58.5 & 44.3 \\
\hline
\end{tabular}

${ }^{a}$ Total metal removal (Metal removed(mg/l) $=$ [Initial Metal Ion] - [Metal Ion in Solution at Equilibrium])

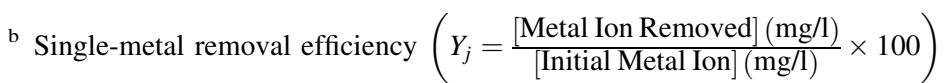

${ }^{c}$ Total removal efficiency $\left(Y_{\text {Total }}=\frac{\sum[\mathrm{Zn}+\text { Cd Total Metal Ion Removed }](\mathrm{mg} / \mathrm{l})}{[\text { Initial Cd }+ \text { Zn Metal Ion }]} \times 100\right)$

Table 2 Extents of $\mathrm{Zn}^{2+}$ and $\mathrm{Cd}^{2+}$ removed (average \pm standard deviation) by D. pleiomorphus at various initial metal concentrations, from single- and binary-metal aqueous solutions, and corresponding bioaccumulation efficiencies

\begin{tabular}{|c|c|c|c|c|c|c|}
\hline $\begin{array}{l}\text { Initial } \mathrm{Zn} \\
\text { concentration } \\
(\mathrm{mg} / \mathrm{l})\end{array}$ & $\begin{array}{l}\text { Initial } \mathrm{Cd} \\
\text { concentration } \\
(\mathrm{mg} / \mathrm{l})\end{array}$ & $\begin{array}{l}\text { Total } \mathrm{Zn} \\
\text { removed } \\
(\mathrm{mg} / \mathrm{l})^{\mathrm{a}}\end{array}$ & $\begin{array}{l}\text { Total Cd } \\
\text { removed } \\
(\mathrm{mg} / \mathrm{l})^{\mathrm{a}}\end{array}$ & $\begin{array}{l}\text { Zn removal } \\
\text { efficiency } \\
-Y_{j}(\%)^{\mathrm{b}}\end{array}$ & $\begin{array}{l}\text { Cd removal } \\
\text { efficiency } \\
-Y_{j}(\%)^{\mathrm{b}}\end{array}$ & $\begin{array}{l}\text { Combined removal } \\
\text { Efficiency }-Y_{\text {total }} \\
(\mathrm{Zn}+\mathrm{Cd})(\%)^{\mathrm{c}}\end{array}$ \\
\hline 60 & 0 & $9.4 \pm 1.9$ & - & 15.7 & - & 15.7 \\
\hline 150 & 0 & $47.1 \pm 7.0$ & - & 31.4 & - & 31.4 \\
\hline 300 & 0 & $83.1 \pm 2.1$ & - & 27.7 & - & 27.7 \\
\hline 0 & 60 & - & $41.4 \pm 3.2$ & - & 69.0 & 69.0 \\
\hline 0 & 150 & - & $58.6 \pm 1.7$ & - & 39.1 & 39.1 \\
\hline 0 & 300 & - & $53.3 \pm 1.8$ & - & 17.8 & 17.8 \\
\hline 60 & 60 & $4.4 \pm 2.7$ & $7.4 \pm 2.8$ & 7.3 & 12.3 & 9.8 \\
\hline 60 & 300 & $8.1 \pm 1.8$ & $29.2 \pm 5.9$ & 13.5 & 9.7 & 10.4 \\
\hline 150 & 150 & $35.4 \pm 4.3$ & $6.2 \pm 2.1$ & 23.6 & 4.1 & 13.9 \\
\hline 300 & 60 & $40.2 \pm 5.2$ & $4.3 \pm 0.6$ & 13.4 & 7.2 & 12.4 \\
\hline 300 & 300 & $2.4 \pm 0.4$ & $11.8 \pm 6.0$ & 0.8 & 3.9 & 2.4 \\
\hline
\end{tabular}

a Total metal removal (Metal removed(mg/l) $=[$ Initial Metal Ion $]-[$ Metal Ion in Solution at Equilibrium $]$ )

b Single-metal removal efficiency $\left(Y_{j}=\frac{[\text { Metal Ion Removed }](\mathrm{mg} / \mathrm{l})}{[\text { Initial Metal Ion }](\mathrm{mg} / \mathrm{l})} \times 100\right)$

${ }^{c}$ Total removal efficiency $\left(Y_{\text {Total }}=\frac{\sum[\mathrm{Zn}+\text { Cd Total Metal Ion Removed }](\mathrm{mg} / \mathrm{l})}{[\text { Initial Cd }+ \text { Zn Metal Ion }]} \times 100\right)$

metal concentration only produced an increase in the amount removed from 60 to $150 \mathrm{mg} / \mathrm{l}$ (between 150 and $300 \mathrm{mg}_{\mathrm{Cd}} \mathrm{l}$, similar amounts were nevertheless observed); the same trend of an increasing bioaccumulation capacity of S. obliquus was observed for both metals when the initial concentration increased from 60 to $150 \mathrm{mg} / \mathrm{l}$; on the other hand, a significant decrease was noticed after exposure to the highest concentration tested (i.e. $300 \mathrm{mg} / \mathrm{l}$ ). Since the metal was removed mainly by adsorption onto the cell surface, this pattern could be rationalized by a release of 
metal ions from the cell wall as a defence mechanism developed by viable microalgae against the toxic effects of heavy metals at higher concentrations. Comparing the adsorption capacity of both species in single-metal solutions, D. pleiomorphus outperformed $S$. obliquus except at $150 \mathrm{mg}_{\mathrm{Cd}} / \mathrm{l}$. Furthermore, taking into account the amount of both $\mathrm{Zn}^{2+}$ and $\mathrm{Cd}^{2+}$ removed by each microalga, the adsorption capacity of $\mathrm{Zn}^{2+}$ was typically lower than that of $\mathrm{Cd}^{2+}$ (except for D. pleiomorphus exposed to $300 \mathrm{mg}_{\mathrm{Zn}} / \mathrm{l}$ ). The highest levels of $\mathrm{Zn}^{2+}$ and $\mathrm{Cd}^{2+}$ uptaken by S. obliquus were $22.3 \pm 8.1$ and $60.8 \pm 8.2 \mathrm{mg} / \mathrm{g}$, respectively, when exposure was to an initial concentration of $150 \mathrm{mg} / \mathrm{l}$; the maximum amounts of $\mathrm{Zn}^{2+}$ and $\mathrm{Cd}^{2+}$ uptaken by D. pleiomorphus were $83.1 \pm 2.1$ and $58.6 \pm 1.7 \mathrm{mg} / \mathrm{g}$, via exposure to initial metal concentrations of 300 and $150 \mathrm{mg} / \mathrm{l}$, respectively.

The simultaneous removal of $\mathrm{Zn}^{2+}$ and $\mathrm{Cd}^{2+}$ from binary mixtures was then compared with the removal amounts obtained in single-metal solutions. For D. pleiomorphus, the amounts of $\mathrm{Zn}^{2+}$ removed in the presence of increasing $\mathrm{Cd}^{2+}$ concentrations and vice versa (i.e. the amounts of $\mathrm{Cd}^{2+}$ uptaken in the presence of increasing $\mathrm{Zn}^{2+}$ concentrations), in combined-metal tests, were lower than those of the corresponding single-metal system-thus indicating lower removal efficiencies (Fig. 1 and Table 2); for instance, the maximum $\mathrm{Zn}^{2+}$ uptake in the latter case was $83.1 \pm 2.1 \mathrm{mg} / \mathrm{g}$ after exposure to $300 \mathrm{mg} / \mathrm{l}$, but such an uptake decreased to $40.2 \pm 5.2$ and $2.4 \pm 0.4 \mathrm{mg} / \mathrm{g}$ when $\mathrm{Cd}^{2+}$ was initially present at 60 and $300 \mathrm{mg} / \mathrm{l}$, respectively-under an identical concentration of $\mathrm{Zn}^{2+}$.

The amount of $\mathrm{Zn}^{2+}$ uptaken by $S$. obliquus in the binary-metal system was higher than in its single-metal counterpart, except at the initial concentrations of $150 \mathrm{mg} / \mathrm{l}$ of $\mathrm{Zn}^{2+}$ and $\mathrm{Cd}^{2+}$ (Fig. 1 and Table 1). Conversely, the amounts of $\mathrm{Cd}^{2+}$ removed were generally lower when compared with their single-metal solutions (except at $300 \mathrm{mg} / \mathrm{l}$ as initial concentration of both metals). Moreover, the amounts of $\mathrm{Zn}^{2+}$ uptaken in this type of solutions were generally higher than those of $\mathrm{Cd}^{2+}$ (except at $60 \mathrm{mg}_{\mathrm{Zn}} / \mathrm{l}+300 \mathrm{mg}_{\mathrm{Cd}} / \mathrm{l}$, and $300 \mathrm{mg} / \mathrm{l}$ of both metals). When in the presence of both $\mathrm{Zn}^{2+}$ and $\mathrm{Cd}^{2+}, S$. obliquus revealed an adsorption capacity of $219.5 \mathrm{mg}_{\mathrm{Cd}} / \mathrm{g}$ after exposure to $300 \mathrm{mg} / \mathrm{l}$ of both metals-thus showing a higher affinity for $\mathrm{Cd}$ ions when the maximum removal extent was achieved.

It was noticed that, in the presence of binary-metal solutions, S. obliquus produced in general a higher removal of $\mathrm{Zn}^{2+}$ than $\mathrm{Cd}^{2+}$ for the combination of concentrations tested, except when $\mathrm{Cd}^{2+}$ was present at $300 \mathrm{mg} / \mathrm{l}$, which led to twice as much $\mathrm{Cd}^{2+}$ removed; hence, a preference towards removal of $\mathrm{Zn}^{2+}$ was observed for this microalga when exposed to the other metal. However, an opposite tendency was revealed by D. pleiomorphus - a preference for Cd ions in binary-metal solutions was indeed observed. Sánchez et al. (1999) reported that, in binary systems encompassing $\mathrm{Cu}$ and $\mathrm{Cd}, \mathrm{Cu}$ was preferentially adsorbed by Cymodocea nodosa. Similarly, Puranik and Paknikar (1999) described preferential uptake of $\mathrm{Pb}$ in binary-metal systems (e.g. $\mathrm{Pb}^{2+}+\mathrm{Cd}^{2+}$ and $\mathrm{Pb}^{2+}+\mathrm{Zn}^{2+}$, among others).

In general, three types of interactive sorption behaviour are displayed by a mixture of heavy metals-viz. synergism, antagonism or lack of interaction. In the former case, the effect of the mixture is greater than the sum of the individual effects of its constituents. In the case of antagonism, the effect of the mixture is less than the sum of the individual effects of the constituents thereof. When no interaction is present, the effect of the mixture is equivalent to the sum of the individual effects (Qi and Aldrich 2008). To determine whether those cation combinations, for either microalga species, interacted in a synergistic or antagonistic manner (or none of them), the removal efficiencies in single- and double-metal ion systems were compared to each other. For instance, using the data tabulated in Table 1 referring to $S$. obliquus, one would expect that the total removal efficiency in the mixture containing $60 \mathrm{mg} / \mathrm{l}$ of each metal should equal $16.0 \%$ (i.e. $11.2+4.8 \%$ ) for a total $120 \mathrm{mg} / \mathrm{l}$ of both metals; however, the observed total removal efficiency was only $8.1 \%$, which represents ca. one half of the total. Consequently, the effect of a second metal upon uptake was found to be unfavourable in terms of total metal removal, although an increase could be noticed in the amounts of $\mathrm{Zn}^{2+}$ removal after addition of $\mathrm{Cd}^{2+}$ in all metal combinations (except at $150 \mathrm{mg} / \mathrm{l}$ of both metals); hence, the interaction between $\mathrm{Zn}^{2+}$ and $\mathrm{Cd}^{2+}$ should be labelled as antagonistic. A similar trend was recorded for D. pleiomorphus.

Recall that the cell wall of microalgal cells is composed of several macromolecules (e.g. peptidoglycan, polysaccharides and proteins) that carry such charged groups as carboxyl, phosphate, hydroxyl or amine, and thus provide binding sites for metal ions (Mehta and Gaur 2005; Puranik and Paknikar 1999). Depending on the prevailing $\mathrm{pH}$, such groups may be either protonated or deprotonated, which obviously affects the extents of metal removal from the surrounding media (Aksu and Dönmez 2006). The most logical reason for the aforementioned antagonistic action would be a similar biosorption mechanism and thus a competitive demand for binding sites on the surface of the microalga cells, associated with mutual exclusion of one metal by the other, owing to stereochemical hindrance (which is expected to be stronger for similar cations). Since a fixed-cell biomass offers a finite number of surface binding sites, the equilibrium uptake would be expected to attain saturation at high total metal ion concentrations, even if the individual concentrations would not cause saturation per se; this does not result only from saturation of 
the biomass, but is also related to interferences between concentrated components that compete for partially overlapped sorption sites.

Aksu and Dönmez (2006) described that biosorption of $\mathrm{Cd}^{2+}$ by the biomass of Chlorella vulgaris (which has cell wall structure and charge similar to those of the microalga species tested in this study) was preferential to that of $\mathrm{Ni}^{2+}$ in binary systems, thus showing a greater sorption capacity for $\mathrm{Cd}^{2+}$ than $\mathrm{Ni}^{2+}$. The inhibitory effect brought about by the presence of another cation in solution may be somehow predicted on the basis of the difference in their class behaviour, as suggested by Nieboer and McBryde (1973). Metal ions can accordingly be grouped into class "a", "b" or borderline ions, on the basis of their covalent indices; both metals used in our study are borderline ions, and Tsezos et al. (1996) claimed that ionic competition is greater (and thus more unfavourable) between metals belonging to the same class. Studies reported by Fraile et al. (2005) encompassing the simultaneous removal of $\mathrm{Zn}^{2+}$ and $\mathrm{Cd}^{2+}$ also by the microalga $C$. vulgaris encompassed all possible binary-metal combinations using $0,10,20,30$ and $250 \mathrm{mg} / \mathrm{l}$ as initial metal concentrations; they showed that the presence of $\mathrm{Cd}^{2+}$ produced a sharp decrease in $\mathrm{Zn}^{2+}$ sorption capacity, so there appears to be a clear affinity of biomass for $\mathrm{Cd}^{2+}$ in the binary system $\mathrm{Cd}^{2+}-\mathrm{Zn}^{2+}$.

However, there is a serious lack of data published regarding metal removal from binary solutions using microalgae; hence, data reported in the literature pertaining to other (micro)organisms were chosen for putative comparison. A similar antagonistic effect was found by Açıkel and Alp (2009) for the fungus Rhizopus delemar, when bioaccumulation of $\mathrm{Cu}^{2+}$ and $\mathrm{Ni}^{2+}$ was reduced by the presence of increasing concentrations of the second metal ion-as compared with single-metal systems. Tobin et al. (1988) pointed out that direct competition appears to exist regarding uptake of $\mathrm{Zn}^{2+}-\mathrm{Cd}^{2+}$ by Rhizopus arrhizus. Mehta and Gaur (2001) reported that $\mathrm{Ni}^{2+}$ and $\mathrm{Cu}^{2+}$ inhibited biosorption of each other, with a competition mechanism involving the same non-specific binding sites. Sheng et al. (2007) reported as well that the uptake capacity of the alga Sargassum sp. for $\mathrm{Pb}$ was reduced in the presence of $\mathrm{Cu}$ and $\mathrm{Cd}$, and that the inhibitory effect of the competing metal ions increased as the concentration of each of those metal ions increased in solution.

In our study, the microalga $D$. pleiomorphus exhibited a net preference for $\mathrm{Cd}$ over $\mathrm{Zn}$ ions, whereas $S$. obliquus behaved the opposite fashion in binary-metal solutions. Those observations are consistent with other studies: $\mathrm{Yu}$ and Kaewsarn (1999) and Mallick (2003) described a lower uptake of $\mathrm{Cu}^{2+}-\mathrm{Cd}^{2+}$ and $\mathrm{Ni}-\mathrm{Cu}$ by Durvillaea potatorum and C. vulgaris, respectively, whereas Aksu et al. (1997), regarding $\mathrm{Fe}^{3+}$ and $\mathrm{Cr}^{6+}$ binary systems, found that the biosorption yields by $C$. vulgaris were reduced faster and faster by the presence of increasing concentrations of the other metal, thus claiming an antagonistic behaviour.

Overall, one realizes that several studies have been performed to test the metal removal capacity of microalgal biomass, but that only a few have used microalgal species isolated from contaminated locations - which have obviously proven to lead to a higher removal capacity than by species obtained from non-polluted environments. On the other hand, only scarce studies have been conducted to test the ability of microalgae to remove metals from multimetal solutions, which are more similar to the effluents found in common practice. Since mixtures of $\mathrm{Zn}^{2+}$ and $\mathrm{Cd}^{2+}$ are typically found in contaminated effluents of industrial processes (Alloway and Ayres 1997), testing of combinations of these two metals would be in order. In this study, it was demonstrated that the two wild microalgae tested are suitable for bioremediation strategies, as both showed a good removal capacity of the two heavy metals. However, there is a competition between the two metals that causes a decrease in the observed overall removal capacity of the metals in the presence of each other, when compared with the single-metal counterparts.

\section{Conclusions}

Microalgal biomass has shown the ability to remove heavy metals from solution, in both single and binary systems. Solutions of two (or more) heavy metal species may experience synergistic or antagonistic interactions with regard to individual metal uptake by microalgae; since mixtures of $\mathrm{Zn}^{2+}$ and $\mathrm{Cd}^{2+}$ are typically found in contaminated effluents of industrial processes, the combined removal capacity should be tested as it better parallels actual industrial effluents.

The adsorption capacity of $\mathrm{Zn}^{2+}$ by $S$. obliquus, when in the presence of $\mathrm{Cd}^{2+}$, is higher than that of $\mathrm{Zn}^{2+}$ alone; hence, $\mathrm{Zn}^{2+}$ was adsorbed preferentially over $\mathrm{Cd}^{2+}$. An opposite trend was observed with $D$. pleiomorphus, for which a preference for $\mathrm{Cd}$ ions in binary-metal solutions was unfolded. Nevertheless, the main finding in this work was that the overall uptake capacity of either microalga species in binary-metal solutions is lower than in the corresponding single-metal systems under similar conditions; hence, competitive adsorption between the two ions appears to exist, which might even be of an antagonistic nature. This point is of major practical interest, since the bioremediation capacity of a microalga regarding a given heavy metal ion may be overestimated if other metal ion(s) is(are) presentwhich is a more likely scenario when dealing with industrial effluents. Therefore, this research effort constituted a first step towards development of a large-scale wastewater treatment process using microalgae. 
Acknowledgments The authors are grateful to Câmara Municipal de Estarreja for permission to access the contaminated site. This work was partially supported by Fundação para a Ciência e a Tecnologia (Portugal) and Fundo Social Europeu (III Quadro Comunitário de Apoio), via a $\mathrm{PhD}$ research fellowship granted to author $\mathrm{C}$. M. Monteiro (ref. SFRH/BD/9332/2002) and supervised by author F. X. Malcata. Author F. X. Malcata acknowledges availability of CBQF premises for performance of part of the experimental work described.

\section{References}

Açıkel Ü, Alp T (2009) A study on the inhibition kinetics of bioaccumulation of $\mathrm{Cu}(\mathrm{II})$ and $\mathrm{Ni}(\mathrm{II})$ ions using Rhizopus delemar. J Haz Mat 168:1449-1458

Aksu Z, Dönmez G (2006) Binary biosorption of cadmium(II) and nickel(II) onto dried Chlorella vulgaris: co-ion effect on monocomponent isotherm parameters. Process Biochem 41:860-868

Aksu Z, Açikel Ü, Kutsal T (1997) Application of multicomponent adsorption isotherms to simultaneous biosorption of iron(III) and chromium(VI) on $C$. vulgaris. J Chem Technol Biotechnol 70:368-378

Aksu Z, Açikel Ü, Kutsal T (1999) Investigation of simultaneous biosorption of copper(II) and chromium(IV) on dried Chlorella vulgaris from binary metal mixtures: application of multicomponent adsorption isotherms. Sep Sci Technol 34:501-524

Alloway BJ, Ayres DC (1997) Inorganic pollutants-heavy metals (chapter 5). In: Alloway BJ, Ayres DC (eds) Chemical principles of environmental pollution. Academic and Professional Publishing, London, p 190

Bishop NI, Senger H (1971) Preparation and photosynthetic properties of synchronous cultures of Scenedesmus. In: Pietro AS (ed) Methods in enzymology. Academic, New York, pp 53-66

Fraile A, Penche S, González F, Blázquez ML, Muñoz JA, Ballester A (2005) Biosorption of copper, zinc, cadmium and nickel by Chlorella vulgaris. Chem Ecol 21:61-75

Mallick N (2003) Biotechnological potential of Chlorella vulgaris for accumulation of $\mathrm{Cu}$ and $\mathrm{Ni}$ from single and binary metal solutions. World J Microbiol Biotechnol 19:695-701

Mehta SK, Gaur JP (2001) Concurrent sorption of $\mathrm{Ni}^{2+}$ and $\mathrm{Cu}^{2+}$ by Chlorella vulgaris from a binary metal solution. Appl Microbiol Biotechnol 55:379-382

Mehta SK, Gaur JP (2005) Use of algae for removing heavy metal ions from wastewater: progress and prospects. Crit Rev Biotechnol 25:113-152

Monteiro CM, Castro PML, Malcata FX (2009) Use of the microalga Scenedesmus obliquus to remove cadmium cations from aqueous solutions. World J Microbiol Biotechnol 25:1573-1578

Monteiro CM, Castro PML, Malcata FX (2010a) Cadmium removal by two strains of Desmodesmus pleiomorphus cells. Water Air Soil Pollut 208:17-27
Monteiro CM, Castro PML, Malcata FX (2010b) Biosorption of zinc ions from aqueous solution by the microalga Scenedesmus obliquus. Environ Chem Lett. doi:10.1007/s10311-009-0258-2

Monteiro CM, Castro PML, Malcata FX (2010c) Toxicity of cadmium and zinc on two microalgae, Scenedesmus obliquus and Desmodesmus pleiomorphus, from northern Portugal. J Appl Phycol. doi:10.1007/s10811-010-9542-6

Nieboer E, McBryde WAE (1973) Free-energy relationship in coordination chemistry. III. A comprehensive index to complex stability. Can J Chem 51:2512-2524

Oliveira RS, Dodd JC, Castro PML (2001) The mycorrhizal status of Phragmites australis in several polluted soils and sediments of an industrialised region of Northern Portugal. Mycorrhiza 10:241-247

Omar HH (2002) Bioremoval of zinc ions by Scenedesmus obliquus and Scenedesmus quadricauda and its effect on growth and metabolism. Int Biodeter Biodeg 50:95-100

Puranik PR, Paknikar KM (1999) Influence of co-cations on biosorption of lead and zinc-a comparative evaluation in binary and multimetal systems. Bioresour Technol 70:269-276

Qi BB, Aldrich C (2008) Biosorption of heavy metals from aqueous solutions with tobacco dust. Bioresour Technol 99:5595-5601

Sağ Y, Kaya A, Kutsal T (2000) Biosorption of lead(II), nickel(II) and copper(II) on Rhizopus arrhizus from binary and ternary metal mixtures. Sep Sci Technol 35:2601-2617

Sánchez A, Ballester A, Blázquez ML, González F, Muñoz J, Hammaini A (1999) Biosorption of copper and zinc by Cymodocea nodosa. FEMS Microbiol Rev 23:527-536

Sheng PX, Ting Y-P, Chen JP (2007) Biosorption of heavy metal ions $(\mathrm{Pb}, \mathrm{Cu}$, and $\mathrm{Cd})$ from aqueous solutions by the marine alga Sargassum sp. in single- and multiple-metal systems. Ind Eng Chem Res 46:2438-2444

Ting YP, Lawson F, Prince IG (1991) Uptake of cadmium and zinc by the alga Chlorella vulgaris: II. Multi-ion situation. Biotechnol Bioeng 37:445-455

Tobin JM, Cooper DG, Neufeld RJ (1988) The effects of cation competition on metal adsorption by Rhizopus arrhizus biomass. Biotechnol Bioeng 31:282-286

Tsezos M, Remoudaki E, Angelatou V (1996) A study of the effects of competing ions on the biosorption of metals. Int Biodeter Biodegrad 38:19-29

Vilar VJP, Botelho CMS, Boaventura RAR (2008) Kinetics modelling of biosorption by algal biomass from binary metal solutions using batch contactors. Biochem Eng J 38:319-325

Yu Q, Kaewsarn P (1999) Binary adsorption of copper(II) and cadmium(II) from aqueous solutions by biomass of marine alga Durvillaea potatorum. Sep Sci Technol 34:1595-1605 